García, A. \& M. Delgado, 1978. Mineralogía de las fracciones arenosas de suelos derarrollados sobre serpentinas en la Sierra de Carratraca (Malaga). Anales de Edafología y Agrobiología 37: 599-620.

Walker, G. F., 1975. Vermiculites. In: J. E. Gieseking (Ed.), Soil components, Vol. 2. Inorganic Components, pp. 155-190. Springer, Berlin.

This synopsis is based on Chapter 6 of the report 'Weathering and soil formation on mafic and ultramafic rocks in N Galicia, Spain' by G. J. van den Born, A. K. Bregt, H. Kok \& J. Zijlstra (editors: P. Buurman \& E. L. Meijer). Research Project J050816 report 1981, 2nd ed. Dept. of Soil Science and Geology, Agricultural University, Wageningen, 1985.193 pp., 32 figs., 24 tables, refs., 12 appendices.

Available as paper copy (order R030P, $f 30$ including postage) or on microfiche (order R030M, f 17.50 including postage) at: NARD, clo Pudoc, P.O. Box 4, 6700 AA Wageningen, Netherlands (telex 45015 blhwg nl.)

\title{
Soil formation on mafic rocks of north Galicia, Spain. 4. Charge characteristics
}

A. K. Bregt ${ }^{1}$, P. Buurman and E. L. Meijer (Department of Soil Science and Geology, Agricultural University, P.O. Box 37, 6700 AA Wageningen, Netherlands)

Received 22 January 1985, accepted 14 February 1985

\begin{abstract}
Point of net zero charge was lower in a serpentinite soil than in a pyrigarnite soil, resulting in a net negative charge in the former and a net positive charge at soil $\mathrm{pH}$ in the latter. PZNC is strongly raised by high free-iron contents, while $\mathrm{pH}$ dependent (CEC) is more strongly related to organic matter than to sesquioxides. At soil $\mathrm{pH}$, positive charge of sesquioxides and negative charge of organic matter approximately compensated each other, and much of the remaining negative charge was due to contribution of layer lattice clays.
\end{abstract}

Key-words: mafic rocks, charge characteristics, CEC, PZNC

Introduction. Exchange properties of soils on mafic rocks are to a large extent determined by iron compounds and organic matter. In 11 soils described from northwest Spain (Van den Born \& Buurman, 1985), total iron (as \% (w/w) $\mathrm{Fe}_{2} 0_{3}$ ) makes up 12-34 \% of the fine earth fraction in serpentinite soils, $4-52 \%$ in soils on chloritized amphibolite, and $7-11 \%$ in pyrigarnite soils, while dithionite-extractable iron

\footnotetext{
1 Present address: Soil Survey Institute, P.O. Box 98, 6700 AB Wageningen, Netherlands.
} 
(as weight $\% \mathrm{Fe}$ ) is $4-22 \%, 2-34 \%$ and $2-5 \%$, respectively. Combined with strongly varying contents and composition of clay, and varying contents of organic matter, contrasts with respect to CEC and Point of Zero Net Charge (PZNC) should be expected.

Materials and methods. Charge characteristics of $\mathrm{Ah}$ and $\mathrm{Bw}$ horizons of profiles $\mathrm{E}$ (serpentinite) and $\mathrm{T}$ (pyrigarnite) were measured in detail. In all samples, three values for exchange properties were obtained.

1. Sum of bases and extractable acidity (SCat) was determined in $1 \mathrm{~mol} / \mathrm{lBaCl}{ }_{2} \mathrm{ex}$ tract, in which also the $\mathrm{pH}$ was measured $\left(\mathrm{pH}_{1}\right)$. In most cases, $\mathrm{pH}_{1}$ was close to the $\mathrm{pH}-\mathrm{KCl}$ of the samples and SCat is therefore an indication of the exchange capacity at soil-pH;

2. After saturation with $\mathrm{Ba}$, an excess $\mathrm{MgSO}_{4}$ was added to the Ba-saturated sample. The $\mathrm{Mg}$ remaining in solution was back-titrated and during the titration the $\mathrm{pH}$ was recorded. This provides a CEC value at a $\mathrm{pH}$ higher than that of $\mathrm{SCat}\left(\mathrm{pH}_{2}\right.$ and $\mathrm{CEC}_{2}$ );

3. CEC at a buffered $\mathrm{pH}$ of 8 was determined by the method of Bascomb (1964), which is another CEC value. The two values for CEC and SCat give an impression of the $\mathrm{pH}$ dependence of the CEC. The two CEC values are obtained by the same method and can be compared without reservation; comparison with SCat meets with some restrictions. The contribution of the clay fraction to the CEC was calculated from the XRFS-analysed Ba content of Ba-saturated clay separates after removal of free sesquioxides. Ba being virtually absent in the parent rock, adsorbed $\mathrm{Ba}$ is a measure of the CEC of the clay fraction at $\mathrm{pH}$ around 5 (the $\mathrm{pH}$ of the $\mathrm{Ba}$ clay suspension before centrifuging). For PZNC determinations $4 \mathrm{~g}$ portions of an oven-dry fine-earth sample were equilibrated with $20 \mathrm{ml}$ aqueous solutions containing different amounts of $\mathrm{KOH}$ (up to $3 \mathrm{ml} 0.1 \mathrm{~mol} / \mathrm{l}$ ) or $\mathrm{HCl}$ (up to $8 \mathrm{ml} 0.1$ $\mathrm{mol} / \mathrm{l}$ ). Equilibration lasted five days, after which the various $\mathrm{pHs}$ were measured and plotted against the amount of acid or base added. Subsequently, $1 \mathrm{ml} \mathrm{KCl} \mathrm{solu-}$ tion, $2 \mathrm{~mol} / \mathrm{l}$, was added to each sample to bring the salt concentration to $0.1 \mathrm{~mol} / \mathrm{l}$, and $\mathrm{pHs}$ were measured after shaking for three hours and plotted in the same graph. Subsequently, $5.7 \mathrm{ml} \mathrm{KCl}$ solution, $2 \mathrm{~mol} / \mathrm{l}$, was added to each solution to bring the salt concentration to $0.5 \mathrm{~mol} / 1$. Again $\mathrm{pHs}$ were measured after five hours shaking, and plotted. The titration curves before and after a specific $\mathrm{KCl}$-addition intersect if the net amount of protons that is expelled from the double layers of clay and organic matter (the CEC components) equals the net amount of protons taken up by the surface of positively charged sesquioxides (the AEC components). Therefore, the $\mathrm{pH}$ of the intersection point must be lower than the PZNC of the sesquioxide(s), and it decreases with a greater number of relocated protons and with smaller amounts of sesquioxides. The number of relocated protons in its turn, is a function of the combined titration curves at different $\mathrm{KCl}$ concentrations of the pure clay and the pure organic matter; it increases with their amounts in the system. The centre of the intersection points of the curves was read as the PZNC of the system. 
Table 1. Selected chemical properties of horizons of profiles $E$ and $T$ (fine earth).

\begin{tabular}{llllll}
\hline Horizon & $\begin{array}{l}\mathrm{pH}-\mathrm{pH}-\text { Org Clay } \mathrm{Al}_{\mathrm{d}} \\
\mathrm{KCl} \mathrm{H} \mathrm{H}_{\mathrm{d}} \mathrm{O}\end{array} \mathrm{Al}_{\mathrm{p}} \mathrm{Fe}_{\mathrm{p}} \mathrm{C}_{\mathrm{p}}$ & PZNC & $\frac{\text { Exchange properties }}{\mathrm{pH}_{1} \mathrm{SCat} \mathrm{pH}_{2} \mathrm{CEC}_{2} \mathrm{CEC} \mathrm{CEC} \mathrm{contr.}}$ \\
& & & $\mathrm{pH} 8$ clay clay
\end{tabular}

Profile E

$\begin{array}{llllllllllllllllll}\text { Ah2 } & 4.3 & 4.5 & 8.0 & 28 & 0.8 & 21.8 & 0.3 & 4.5 & 3.4 & 3.9 & 4.2 & 102 & 5.2 & 112 & 391 & 570 & 161 \\ \text { Bw } & 5.2 & 5.6 & 1.0 & 26 & 0.1 & 11.8 & 0.0 & 0.4 & 0.5 & 3.5 & 5.7 & 151 & 6.4 & 180 & 260 & 644 & 169\end{array}$

Profile T

$\begin{array}{llllllllllllllllll}\text { Ah } & 4.4 & 4.0 & 9.1 & 19 & 1.5 & 5.0 & 1.1 & 1.8 & 4.5 & 4.6 & 4.4 & 117 & 5.6 & 110 & 430 & 448 & 83\end{array}$

$\begin{array}{llllllllllllllllll}\mathrm{Bw} & 4.5 & 4.3 & 1.6 & 18 & 1.1 & 3.5 & 1.0 & 0.9 & 1.5 & 4.7 & 4.7 & 38 & 5.8 & 5 & 223 & 249 & 44\end{array}$

$\bar{d}=$ dithionite extraction; $p=$ pyrophosphate extraction; $\mathrm{pH}_{1}=\mathrm{pH}$ of cation extract; $\mathrm{pH}_{2}=\mathrm{pH}$ of $\mathrm{CEC}_{2}$ determination; contr. clay $=$ clay percentage $\times C E C$ of clay fraction. $C E C$ and $S C a t$ values in $\mathrm{mmol} / \mathrm{kg}$; contents in weight percentages.

Results. Relevant chemical data of the four horizons for which the PZNC was determined are given in Table 1.

In accordance with theoretical considerations, $\mathrm{pH}-\mathrm{KCl}$ is lower than $\mathrm{pH}-\mathrm{H}_{2} \mathrm{O}$ if soil $\mathrm{pH}$ is above $\mathrm{PZNC}$ (profile $\mathrm{E}$ ), and higher than $\mathrm{pH}-\mathrm{H}_{2} \mathrm{O}$ if soil $\mathrm{pH}$ is below PZNC (profile T).

In profile $\mathrm{E}, \mathrm{PZNC}$ of the $\mathrm{Ah}$ is higher than that of the Bw. Clay contents, and also the contribution of the clay fraction to the CEC being similar, we may conclude that the negative shift in PZNC due to a greater organic carbon content $7 \%$ more in $\mathrm{Ah}$ ) is less than the positive shift due to a greater sesquioxide content (10\% more $\mathrm{Fe}_{\mathrm{d}}$ and $0.7 \%$ more $\mathrm{Al}_{\mathrm{d}}$ in $\mathrm{Ah}$ ).

In profile $\mathrm{T}$, the PZNCs are considerably higher. Here, a difference of $7.5 \% \mathrm{C}$ has slightly more influence than the difference in sesquioxide content $(1.5 \%)$. In this profile, a greater fraction of sesquioxides, especially $\mathrm{Al}$, is bound in organic complexes. The high PZNCs will be partly due to high kaolinite and gibbsite contents in the clay fraction. CEC shows a strong $\mathrm{pH}$ dependence. Like in other profiles the calculated contribution of the clay fraction is sometimes higher than SCat, which indicates that in the untreated sample part of the clay charge is blocked by sesquioxides. In three samples of Table 1, the clay contribution is of the same order of magnitude as SCat. This indicates that at $\mathrm{pH} 5$ an amount of negative charge equivalent to the contribution of organic matter is blocked by sesquioxides. In the Ah of profile E, however, SCat is considerably lower than the clay contribution, which may be explained by the very high $\mathrm{Fe}_{\mathrm{d}}$ content of this horizon.

In all profiles investigated, samples with high organic matter contents have a steeper rise in $\mathrm{CEC}$ with $\mathrm{pH}$ than samples with high sesquioxide contents. Samples with similar organic matter contents (3-3.5\%) and varying sesquioxide contents $\left(14-33 \% \mathrm{Fe}_{\mathrm{d}}\right)$ had a similar increase of $\mathrm{CEC}$ with $\mathrm{pH}$ and it was not possible to specify the effect of sesquioxides. 


\section{References}

Bascomb, C. L., 1964. Rapid method for the determination of cation exchange capacity of calcareous and non-calcareous soils. Journal of the Science of Food and Agriculture 12: 821-823.

Van den Born, G. J. \& P. Buurman, 1985. Soil information on mafic rocks of north Galicia, Spain. 1. Soil genesis and classification. Netherlands Journal of Agricultural Sciences 33: 62-64.

This synopsis is based on Chapter 7 of the report 'Weathering and soil formation on mafic und ultramafic rocks in N Galicia, Spain' by G. J. van den Born, A. K. Bregt, H. Kok \& J. Zijlstra (editors: P. Buurman \& E. L. Meijer). Research Project J050816 report 1981, 2nd ed. Dept. of Soil Science and Geology, Agricultural University, Wageningen 1985. 193 pp., 32 figs., 24 tables, refs., 12 appendices. Available as paper copy (order R030P, $f 30$ including postage) or on microfiche (order R030M, $f$ 17,50 including postage) at: NARD, clo Pudoc, P.O. Box 4, 6700 AA Wageningen, Netherlands (telex 45015 blhwg $n l$.)

\section{Heterogeneity of Dutch rainfall}

J. V. Witter (Department of Hydraulics and Catchment Hydrology and Department of Mathematics, Agricultural University, Wageningen, Netherlands)

Received 16 January 1985; accepted 19 February 1985

Abstract. Rainfall data for the Netherlands have been used to investigate aspects of heterogeneity of rainfall, in particular local differences in rainfall levels, time trends in rainfall, and local differences in rainfall trend. The possible effect of urbanization and industrialization on the distribution of rainfall has also been studied. Consideration has been given to whether local differences in rainfall justify a partition of the Netherlands into regions. Finally, the degree of areal reduction in hydrological design based on variation of rąinfall in time and space has been investigated. Key-words: rainfall, trend, local differences, urban precipitation enhancement, kriging, areal reduction factor.

Trends in rainfall. The rainfall characteristics used in the investigation of homogeneity in time and space are total annual rainfall and annual frequencies of exceedance during the summer or the winter period of certain threshold values $(1,15$ and $25 \mathrm{~mm}$ ) of daily rainfall. Time trends in these rainfall characteristics averaged over the Netherlands have been estimated. For the period 1951-1979, the time trend is negative for the summer period; for the period 1906-1979, the time trend is posi- 